\title{
PUBLIC TORT LIABILITY ADMINISTRATION: BASIC CONFLICTS AND PROBLEMS
}

\author{
Leon Thomas David*
}

For some years, lawyers and law teachers have exhibited an increasing interest in the liability of public agencies in tort. Academicians have asserted that large groups of litigants were denied justice by the immunity of public agencies from suit, particularly in tort. Practitioners have come forward with specific instances in which recoveries have been denied upon the ground of this immunity, and continually recurring cases involving the doctrine have reached the appellate courts, provoking further discussions in legal journals. It has been argued, time after time, that the legal equality of the sovereign and the subject is the essence of just law and that justice is outraged because governmental agencies are not held liable in situations which ordinarily have permitted legal recovery against private parties.

There is no doubt that this attack has carried the outposts of governmental immunity in tort, in that the dicta of courts reveal considerable juristic sympathy for litigants denied recovery against governmental agencies. But many decisions proclaim the continued existence of the immunity. Legislative action to set aside the limitations on suit against governmental agencies is strongly resisted. When consent to suit is forthcoming, it may be hedged about by conditions which complicate suit or discourage it altogether. The vitality of the policy of immunity, in the face of attacks based upon arguments of "justice" and "morality" must rest in facts not revealed by abstract consideration of the cases. When any legal policy remains static, there must exist competing public policies which have produced equilibrium. Or are those policies dictated by administrative difficulties? Can it be that other remedies than suit are available and adequate?

To seek further light on these questions, the Social Science Research Council agreed to sponsor a study relating to the administration of public tort liability in the

- A.B., 1924, J.D., I926, Leland Stanford Jr. University; M.S. in Pub. Adm'n, r935, University of Southern California. Member of the California Bar. Lieutenant Colonel, United States Army, now Assistant Commandant, School for Special Service, Fort George G. Meade, Md. Assistant Professor and Director of the Legal Aid Clinic, School of Law, x93I-I934, lecturer, Schools of Law and of Government, 1934-1941, University of Southern California; Assistant City Attorney in charge of Torts Claims Division, Los Angeles, since I934 (now on leave); Deputy City Attorney, Palo Alto, California, I927-r93I; President, City Attorneys' Section, League of California Municipalities, I930, director of League, 1931-1932, member of legislative committee, 1927-1930. Author, "Municipal Liability for Tortious Acts and Omissions" (1936); co-author of a study of the administration of municipal tort liability claims in Los Angeles published by the Committee on Public Administration, Social Science Research Council, I939. Contributor of articles on public tort liability to legal periodicals. 
City of Los Angeles. The law of municipal tort liability in California already had been summarized and studied in relation to the law of other states. California's social legislation and the social attitudes of its courts were thought to be advanced. The interest of city attorneys in such a study was manifest. Hence, it was hoped the study would be beneficial for the facts developed and also as a pilot study for similar research elsewhere. Similar studies were made later in Boston and Medford, Massachusetts; Austin, Texas; Chicago, Illinois. Partial data were secured by conference and otherwise from the Virginia League of Municipalities, New York City, and Scranton, Pennsylvania. ${ }^{1}$

In the studies and in the conference which followed, in which the authors of the studies jointly considered the subject, aided by Professor Edwin Borchard, long the antagonist of governmental immunity from suit in tort actions, administrative factors received careful attention, and statutory developments were also discussed. Many of the conclusions drawn may appear among the various views expressed in this issue of Law and Contemporary Problems. In this article, however, it is intended to suggest basic factors affecting the tort liability of municipalities, in substantive law as well as procedure; and also to sketch some attitudes and arguments bearing on the existence of the immunity doctrine in the courts; to consider the factors which have made legislative determinations unsatisfactory; and some of the characteristics which have led most recent studies to advocate administrative, rather than judicial, determination of claims arising out of tortious acts and omissions. The views herein have been developed and tempered considerably by the researches and conferences already referred to, but are presented as individual, rather than group, conclusions arising from the studies that have been made.

To lawyers, research always suggests the patient attempt to find, read, analyze and digest the reported cases. In this field, as in all other fields of municipal corporation law, the statutes rather than the cases are the most important element. There is little, if any, law which could be called common law, except the common thread be found in the statutes applied and interpreted in the cases. The extent of the problem of municipal tort liability, or the extent of the injustices allegedly arising out of the doctrines expressed in appellate reports, cannot be gauged from the cases. Presumably the appellate cases reflect the new and unsettled, rather than the old and settled, questions of law. The important factor is the number of every-day determinations based on the settled doctrines and the administrative difficulties, if any, arising therefrom.

By confining attention to the reported cases, the place of immunity from suit as a doctrine of public law has been unduly magnified. The existing statutes permitting suit against municipalities for injuries caused by dangerous and defective conditions of streets, and providing a legal remedy in automobile cases, give a remedy in $90 \%$ of the instances where injury is claimed, viewing the assertions of liability quan-

\footnotetext{
${ }^{1}$ For a further deseription of these sudies, see French, Research in Public Tort Liability, supra p. 234. ED.
} 
titatively. The disputes concern a variety of facts and circumstances whose uniqueness has overemphasized their importance from a social viewpoint. In fact, statutes providing for liability for injuries resulting from dangerous and defective conditions of highways are among the oldest on the statute books in some states.

Do, then, alleged defects in justice arise out of facts extrinsic to the immunity doctrine? How far do the deficiencies of daily governmental administration aid or defeat the just claim? To what extent do such deficiencies differ in kind or degree from those recognized to exist in tort litigation between private parties?

At the outset of any study involving these questions, the reader must determine his point of view as to the end to be attained. For many years, the principal objective urged has been to make government amenable to legal processes to the degree that a private person would be, under same or similar circumstances. Equality will restore justice, under this theory. Lately, other objectives have crept in. In private litigation, the deficiencies of remedy resulting from the financial inability of defendants to respond to judgment has given rise to movements for compulsory insurance. In public litigation, there has been a trend to make governmental agencies the insurers of safety of their public works. Workmen's compensation systems have been set up affording compensation, irrespective of old doctrines of liability based upon fault. Much of the irresolution of legislatures and the public in extending public tort liability is to my mind due to conflicting theories, on the one hand going back to the tort liability based upon fault or imputed fault and, on the other, urging financial responsibility based on an administrative capacity to spread a "social cost."

\section{Conflicts of Theories Underlying Public Tort Liability}

The author of a harm to another is not always required to make compensation in money to that other, because of the act or omission which occasioned the injury. There are certain harms for which the payment of compensation will be enforced by the courts, backed up by the power of the state to compel the payment to be made from the property of the tortfeasor. Abstract justice seems to require that the one directly causing or instigating an injury should make recompense. On this has been engrafted pecuniary responsibilities arising out of status; the master has been made liable for the act of the servant, the husband for the feme covert, the parent for the child. These liabilities rest upon social policies. They have not remained static, as the law of husband and wife will demonstrate. In the interest of providing compensation for the injured party, these fictions for transferring pecuniary responsibility may be useful. They do not necessarily rest on abstract justice or morality. Anciently, financial responsibility for the shortcomings of $A$ might be placed upon $B$, on the basis of relationships implying if not involving actual physical control of the wrongdoer. The pater familias or firthpledge system made $B$ the hostage for the proper behavior of those bearing special relationships to him and his household. The actor, then as now, was liable; and the additional imputation of liability was designed to serve as a social control, to prevent future neglects or wilful misdeeds, as well as to 
restore the injured party to his former condition, or to compensate him for detriments by the payment of money.

Many believe that abstract justice requires no more than that the one causing the injury should be forced to make amends for it by payment of compensation. To force $B$ to make good $A$ 's neglect to $C$, because $A$ is insolvent, may wrong $B$, who did not command, control, or cooperate in a tort. The justification, where not resting in an actual control of $B$ over $A$, must rest in the argument that $B$ can recoup from $A$ better than $C$ can collect, or that $B$ in turn may pass on the burden to a large group of persons, who severally will not be conscious that they are making good $A^{\prime}$ 's neglect. Rather than see $C$ suffer, the "social cost" will be spread.

Herein we see a nice balance between justice, predicated upon individual fault, and a social policy which tries to minimize the detriment to $C$, quite apart from initial fault. The imputation of liability, in order to assure recompense to $C$, the injured party, rests upon the fiction of identity between master and servant, husband and feme covert, and so on. Whether that fiction will be indulged in any instance depends upon the social necessity of making $C$ whole. The emancipation of women has led to elimination of the fiction in the law of domestic relations, pro tanto, as the years roll on. The degree to which it was desired to afford social protection to the workingman was too great for the fiction to withstand, so the fiction was scrapped. Workman's compensation, not depending on fault, was substituted.

That governmental agencies are not liable to suit in the courts for the torts of employees or officers rests principally on the fact that here neither courts nor legislatures have been willing to establish the fiction of identity, to give effect to the doctrine of respondeat superior. The wilful or negligent act of an officer or employee is his tort alone, where the doctrine of immunity prevails. The injured party may collect from him. The arguments for transferring the liability to the body politic assume that the injured party cannot secure adequate recompense in this manner. Assuming that the officer is insolvent, the situation is no different from that which prevails in many cases between private parties. Conversely, where the operations of government become complex and potential liabilities great, it may be argued that it is necessary to take the burden of liability from the officer, lest the public be handicapped in securing men to administer government. Historically, it has been urged that the threat of liability hanging over the officer or employee is one of the most powerful aids to good administration; that the salutary effect of personal liability, with no opportunity to shift it to the public agency, is a social necessity which outweighs the social interest in compensating an injured party who may not be able to collect from the official because of the latter's inability to respond in damages.

Undoubtedly, the legal characteristics of the municipal corporation complicate the imputation of liability to it for the torts of its officers and agents. The public corporation is a creature of statute, living with artificial respiration in an iron lung provided by the legislature. As a person, it is entirely a fiction; to make it responsible for torts in the same manner and degree as a man of flesh and blood, requires many 
legal assumptions. First of these is that of a comparable freedom of action. This certainly it does not have. The private corporation in many states has much more, so comparisons with it are not conclusive. For instance, in one state a business corporation may engage in any business permitted a private person, with complete freedom of organization and action, save where positive statutes intervene. But whereas the business corporation may do anything not prohibited, choosing any appropriate means, the municipal corporation cannot act unless positively authorized, and then the procedures prescribed for it become the quantum of its power.

Can we under such circumstances transpose the obligations of a private individual to the municipal corporation? Can we use the same statutes or the same cases to establish what is the "conduct of a reasonable man" under the circumstances? The difficulties of subjecting a jury to all the successive fictions of identity and conduct in such a process are enormous. Therefore, my own convictions, based on experience, are that tort liabilities of government should be based on statutory definitions of duty. Indeed, this is the trend. But the rigidity of such statutes as compared to the freedom afforded juries in ordinary tort liability actions gives rise to complaint that the statutory rights perish in the meshes of the procedure for asserting them.

\section{II..Conflicts in Public Atritudes Undertying Public Tort Liability}

The powers and duties of municipal corporations have been classified by the courts as "governmental" and "proprietary," and suit has been permitted against such corporations for injuries arising out of their "proprietary" activities. ${ }^{2}$ In applying the governmental-proprietary test, the English courts, under a centralized government, have met few difficulties of logic or application. But in the United States, with a great diversity of jurisdictions, there has not been unanimity. The scholar, having before him the decisions of many states, concluded logically that where there was such diversity of opinion, the doctrine of immunity itself as a social policy was questionable.

This, to some degree, is a non sequitur. It is the main purpose of local government to permit variations in local policy, reflecting the needs, opinions and attitudes of the governed. Is not fundamental justice achieved when all establish and are governed by the local rules? In any country as diverse as ours in geography, populations, activities, and beliefs, these rules and concepts are varied. There is no essential lack of logic in determining that it is a governmental function in Texahoma tc

\footnotetext{
I In the United States, in denying immunity for proprietary activities, the courts and legislatures alike have ignored a difference in the birth of English and American municipal corporations. In England, where cities in some instances had a corporate character antedating the rise of strong central control by the Crown, their powers were not considered to be derived from the Crown. The duties performed for the Crown were apt to be contractual or to arise out of feudal status. As agents of the Crown, cities were sovereign to the extent of the agency and no more. Beyond that, they were regarded essentially as private corporations, amenable to the processes of the courts. Since in the United States no municipal corporation has powers sui generis, it may be said that all powers delegated to a city are sovereign, or governmental, in that they result from parceling a part of the power possessed by the state.

Counties generally partake of the sovereignty of the state since they are administrative units through which the state performs its functions. Suit against a county is therefore considered suit against the state, as a general rule.
} 
furnish ice in summer or wood in winter in Minneconsin; while at the same time refusing to recognize the converse relative to wood in Texahoma or ice in Minneconsin. This is a question of local policy. To decide whether or not social policy requires that either state accept pecuniary responsibility for the shortcomings of employees engaged in either function, it is necessary to take into account the local concepts of the duty of care owed by government. To pretend that this is a constant across America is to deny our entire political experience.

In rural areas, and even in urban areas in the New England states, the South and West, local government exists primarily for regulation, and not as a convenient organization to undertake essentially business services for the people. This not only is a matter of the tax base; it is tied in with philosophies of government's place and responsibility. Poor concrete sidewalks are better than mud; rough uneven slabs are better than none at all. One spraining an ankle thereon is apt to be met with the query of his neighbor, "You must not have been looking where you were going" rather than, "It's a dirty shame the city has such a miserable sidewalk." If it required a sizeable tax levy in the small town to produce that public work, the resulting pride in it precludes any special sympathy for one claiming injury thereby. In some localities, such improvements, "scrimped for" by all, are to be taken as they are. "Some improvement is better than none." One who sues for an ordinary injury there might be regarded as antisocial. In metropolitan areas, however, where public improvements are extensive and expensive, and where the tax base is broad, there is a contrary trend.

Herein, we meet a vital factor in any study looking to the extension of liability and the negation of immunity.

"Where the tax base is not broad, the individual taxpayer-citizen is touched immediately by levies imposed to meet liabilities. His proportion may be small; but in a small community, he is fully advised of the circumstances. He believes that taxes are forced contributions, not service charges. He will rebel at the idea he is paying for the carelessness of a city ditchdigger. He does not pay for the injuries his brother, father or mother causes; why is it just he should pay for the shortcomings of one whose status in relation to him is even more remote? In other words, he does not accept the "social cost" theory which in these times is the lifeblood of the imputed liabilities. Furthermore, he is apt to know that in the vast majority of our local governments, administrators, employees or part-time officials neither profess nor possess any special training for their work. In statutes and charters, he and his fellows have carefully defined, limited, and restricted their powers in recognition of this very fact. Likewise, he believes that proper andicareful performance of their duties to the public is best obtained by holding the specter of personal liability before those officials. $\mathrm{He}$ feels that they would shift those liabilities onto the general public in every case, if the governmental agency was liable along with the official.

How different the picture in the metropolis, whose charter attests the expansion of government! Any liability is passed on, over a wide base. At the same time the capacity of the city to pay for better improvements and works, to hire better-trained 
personnel, is greater. The individual taxpayer is an insignificant factor in this administration, either in the voice he has in affairs or in the few mils of his taxes which represent judgments against the city.

Both groups send their representatives to the legislature. The incapacity of the small community, county or school district to meet widespread liabilities is usually an argument against extending liability. The larger cities are not anxious to extend their fiscal responsibilities and they may be expected to oppose any plan whereby their contributions to a state fund will be used to subsidize the smaller city's losses. In some states, methods to spread payment over-several years are employed. Sometimes bonds may be issued to provide immediate funds to pay liabilities, thus permitting the burden to be spread over future years.

Philosophically, an award of damages is at best an incomplete or doubtful remedy. Where property is concerned, man's ability to replace or repair what man has created, given time and money, may make this remedy substantial; but, even so, lost time is never found again. In the field of personal injury or death claims, the remedy of damages is uncertain and unsatisfactory justice. The dead cannot be brought to life; the miracles of science do not restore the injured party to a previous condition. Here, the "special damages" caused by the wrong may be assessed with greater facility than those termed the "general damages." General damages must always remain an uncertain factor mathematically. These damages, resting upon the judgment of a court or jury, are unlimited, save when their excess is ascribed to "passion or prejudice." This in turn is a legal formula used to reach those instances in which a reviewing court believes the individual award to be out of line with an ill-defined bracket within which such awards customarily fall. Thus the amount of the award is conventional, rather than compensatory, and the award itself is made primarily as a social deterrent of prohibited conduct. From time to time, certain classes of defendants are amerced more than others; in certain localities, certain torts are heavily compensated, in variance from other localities.

Tort litigation, in its practical aspect, is primarily a gamble over these general damages. The variances and uncertainties attending such awards have given rise to most of the movements for improvement in court procedures. This has been accelerated by the tremendous growth of automotive transportation, with resulting litigation. Likewise, this gamble has led to the abuses which attend the field. It has led to the malingerer and the ambulance chaser, the manufacturing of evidence, and the contingent fee. The awards of damage, like taxes, have been levied according to an ability to pay-"It takes a greater award against a rich corporation to deter future wrongs, than it would against an individual."

Logic indicates that the fear of abuses should not prevent extension of public liability, if necessary to do justice. Experience indicates that municipal corporations and other governmental agencies were once fair game in predatory litigation. Juries in metropolitan areas have been fully as biased as rural juries were in railroad litigation fifty years ago. The recent studies show that these tendencies perhaps are not as marked in the cities of Los Angeles, Boston, Medford, and Austin as public law 
officers report them to be elsewhere. One may suspect that careful statistical studies over a large number of cities would show that the old tendencies to fleece the public agency are disappearing. Meticulous preparation of the defense in Los Angeles has destroyed the major opportunities for the ambulance chaser.

Nevertheless, legislatures have hesitated to pass the statutes necessary to enlarge the rights of suit against governmental agencies, based upon the fear of victimization. The widespread location of governmental property and undertakings; the right of members of the public to use public property, irrespective of their purpose or condition; and the consequent absence of the detailed supervision present in a more limited private enterprise, have helped to place municipal corporations at a disadvantage in litigation. Taking advantage of liberal statutes of limitations, litigants have waited till the last moment to file actions involving alleged injuries from minor sidewalk defects. Since the injury occurred, the defective walk may have been repaired, the witnesses dispersed, and the employees charged with maintenance discharged. Under such circumstances, where all evidence is absent save the plaintiff's, fraud is facilitated. Hence, we find the legislatures requiring the filing of a claim as a condition precedent to suit. This procedure, discussed in more detail elsewhere in this symposium, is equally applicable to systems which provide for legislative or administrative settlement of claims.

In devoting this attention to the doctrine of immunity, it is not intended to argue for or against its perpetuation. The considerations advanced are those which explain its vitality. The reader may think some of the considerations are trifling, others novel, and that still others involve matters of general public administration upon which he has no insight. But though some may seem specious or inapplicable, others are more actual than academic. Whatever weight be given them, these and similar attitudes and situations have led lawmakers to move slowly in extending liability, or have induced public officials to oppose the extension.

To the degree that liability can be administered without dislocating governmental finances, most of the objections will disappear. This is largely the problem of the small city. To the degree that the duties of care devolving upon public officials are made statutory, many other objections can be overcome.

\section{Problems in the Legislative Determination of Public Tort Liabiuttx Claims}

As against state governments, statutes sometimes authorize courts to try the facts in tort actions, certifying the result to the legislature which thereafter may appropriate the funds to pay the tort claim. In general, this is a survival of the English system. But, usually, barring constitutional restrictions, state legislatures may pay such claims directly. Many state constitutions, however, require that general laws be adopted and prohibit individual legislation where a general law might serve. Others have provisions interpreted to prohibit payment of claims not supported by legal, as contrasted to moral, consideration. This becomes very restrictive when claims upon which recovery could not be had in the courts are held to be supported only by moral consideration. 
Although available, legislative payment may be a very unsatisfactory remedy against state government. It is not speedy; it throws every claim into an arena in which political considerations may weigh heavily; there may be wide disparity of treatment of similar claims; time and facilities, as well as personnel, may be lacking for painstaking consideration of the facts by the legislature.

To require a legislator to introduce a resolution or bill for payment of a claim has disadvantages to both the claimant and the legislator. The legislator may give or withhold his sponsorship for political reasons. He may be reluctant to sponsor a claim at all, since he may not be equipped to carry the burden cast upon him of learning the facts. If he introduces a tort claim for one constituent, he will be deluged with similar requests. If a claim should happen to be paid, the praise of the satisfied constituent is offset by the denunciation of others whose more questionable claims the legislator has refused to advocate or the legislature has rejected. To avoid becoming involved in such a snarl which affects his capacity to be effective in major legislation, the legislator will seek to shift the burden. This may be done by refusing all consideration of tort claims as a legislative subject, saying "Let the courts decide." Instead the burden may be shifted to administrative processes in which controllers, auditors, and law officers play an important part.

The claimant, experiencing a succession of legislative hearings on his claim, subjected to cross-currents of policy, and beset by delay, does not favor the legislative settlement. He turns to the courts, only to find that in a large field of relations between the community and the individual, the courts have not been constituted agencies to handle such claims; the necessary delegation of power has not been made; "consent to suit" has not been given. Where such delegation has been made, he finds still that the judicial process of determining his claim is subject to the infirmities of litigation, of which delay is now the chief. He feels that it would be desirable to have agencies with which his claim could be speedily considered and adjusted. He thinks in terms of modern insurance practice. Indecisive and dilatory at times, still the commercial companies in routine matters allow negotiation and compromise, with legal warfare as a final but not the only procedure.

In cities, the local legislative body engages in a similar process of shifting responsibility. Sometimes this is discovered in the unwritten procedures of the city, the council rules, or the charter or other organic city law. The city attorney or corporation counsel usually falls heir to the administration of tort claims. This tendency is visible as soon as a city becomes large enough to employ full-time counsel. $\mathrm{He}$ is expected to be a fact-finding agency on claims in tort. If he reports favorably on a claim, the councilman in turn can reenforce his favorable vote with legal authority, while retaining full capacity to criticize the recommendation on any and all grounds if he desires to contest it. The facts, in any event, are usually more fully developed than the councilman would develop them. If the attorney reports adversely on a claim, the councilman is politically reenforced in denying compensation. He can rest upon the legal opinion; he can claim he would become liable in a taxpayers' suit, should he vote to pay after the opinion was received; and he can always assert that 
he personally favored the claim, and regrets it could not be paid for "legal reasons." Incidentally, this last procedure has had an immense effect on the public attitude toward the administration of public liability claims. It has led in part to the belief that meritorious claims are denied on technicalities peculiar to cities.

\section{Problems in the Judictal Determination of Public Tort Liability Claims}

Bit by bit, the tendency is to enlarge the power delegated to the courts to determine tort liability claims. In part, this has been accomplished by establishing that municipal corporations or agencies are "persons" within the scope of the judicial process; and, to the degree that they are state agencies partaking of the state's sovereignty, by action of the state in delegating power to administer such claims to the courts. ${ }^{3}$

The Social Science Research Council survey, embracing the experience of such diverse communities as Los Angeles, California, Chicago, Illinois, Boston, Massachusetts, Medford, Massachusetts, and Austin, Texas, does much to illuminate the character of the claims submitted to courts. Clearly, injuries arising from the operations of motor vehicles, and those arising from the condition of public buildings, streets, works and grounds, are the two major classes. Street and sidewalk defects were responsible for $7 \mathrm{r} \%$ of the $\mathrm{r}, \mathrm{g} 06$ claims reported upon. A large proportion of the vehicle accident rate resulted from operation of garbage and refuse trucks. There are great variations in the precise bases of the claims, due to the different localities, climate, and age of properties in each of the cities concerned.

Except where vehicles such as police cars, ambulances and fire department trucks, are concerned, the trial of the action for negligence arising out of motor vehicle mishaps presents little variation from ordinary negligence actions of the same character between private individuals. Actually, there has been no study to date comparing the experience of litigants in private suits with that of litigants having public adversaries, from which it can be concluded that the claimant fares worse with the public defendant than he would with a private one. Most of the infirmities alleged against the administration of public tort liability inhere in personal injury litigation generally. There is no legal or social reason why recoveries against public bodies should be broader in scope, or easier to obtain, than recoveries against private litigants. The average private litigant cannot pass on the "social cost"; we do not hold him as an insurer of the safety of all others. But it must be admitted that many attempts to expand the tort liability of governmenal agencies tend toward liability without fault.

The Role of Judicial Determination. It would seem desirable to regard litigation as the last resort, used only to settle matters of law and fact, where the issues are fairly debatable and cannot be settled by compromise, each party having an equally good case. If this condition were to obtain, might it not be expected that in a great number

\footnotetext{
${ }^{8}$ Where, after adjudication, payment rests in the discretion of a legislature, it is believed this is an administrative, rather than a strictly judicial, process. Courts frequently have power to enforce payment by local governmental agencies of tort judgments and, as this process is akin to private litigation, it is probably judicial, by the usual definitions.
} 
of cases, the judicial determinations would tend to result in a $5^{0-50}$ division of judgments? There are many dangers in attempting to evaluate the dissimilar figures presented in the survey, but the broad picture can be presented. If we regard compromises after suit as concessions to plaintiffs, and add these to the judgments they receive on the merits, we can see the following:

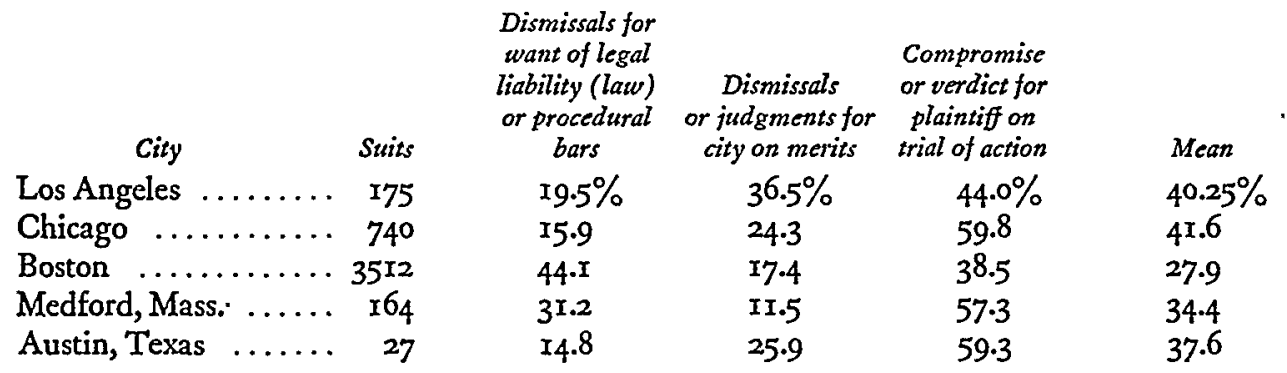

From the table, it would appear that Los Angeles most nearly approximates the ideal. Approximately $80 \%$ of the suits there were disposed of on their merits. If verdicts had been evenly divided, the city and plaintiff each would have had judgment or decision in $40.25 \%$ of the suits. The claimant recovered in $44 \%$ of these instances. Hence it seems that: (I) the administration of tort claims, in cases which the city refused to settle, was efficient; and (2) that justice was done to the claimant in that, on the whole, the existence of evenly divided conflicts of opinion as to law and fact in the litigated matters was indicated by the ultimate settlements and recoveries.

Any wide variation from evenly distributed recoveries or dismissals on the merits may indicate litigation where the merits might have justified settlement by the city. In the cities other than Los Angeles, litigation was carried on in cases where the odds were from $70 \%$ to $85 \%$ against the city. Thus, in these cases the city may have been held liable in verdicts in excess of the amounts for which it might have compromised. Similarly, the claimant may feel he has been forced to litigation in a case where the issues were relatively in his favor. Thus in Austin, Texas, where officials indicated that they believed their policy of settlement to have been liberal, the city had judgment on the merits in only $30 \%$ of the cases.

Dismissals on procedural points, or for want of legal liability under statute, range from $14.8 \%$ of the cases in Austin, Texas, to $44.1 \%$ of the cases in Boston. This defies any attempt at interpretation. The high proportion of such cases dismissed in Boston may result from ignorance of municipal corporation law by attorneys bringing such ${ }^{\circ}$ suits or from attempts to force small settlements in doubtful cases. Why cases are not filed before statutes of limitations run cannot be explained by generalizations; and the dismissals for want of prosecution generally are chargeable to the claimant's poor chance of recovery, either under the facts or the law, or to the cost of prosecuting the case in proportion to the recovery possible.

Delay in Judicial Determination. This is common to all tort actions. The crowded calendars of courts in metropolitan areas preclude prompt trial of cases. 
Many actions are filed by claimants before their causes are prepared for trial; and even where cases are accelerated, all delay would not be avoided. There is little evidence in the current studies to indicate that the municipal bodies concerned interpose needless delays in the prosecution of tort actions. The preliminaries cost the claimant much time. Ordinarily, no suit may be brought until the "administrative remedies" have been exhausted. These contemplate the filing, consideration and rejection of a claim by the municipal officers before a cause of action accrues. Litigants have complained that they have grown gray-haired in this process. In some states, as in California, claims against governmental bodies are deemed rejected, so as to permit suit, after the lapse of a "reasonable time" or of more definite statutory periods. Against counties, this period in California is six months.

The time element is indicated in the various studies as follows:

\begin{tabular}{|c|c|c|c|c|c|}
\hline $\begin{array}{l}\text { Average Period Between } \\
\text { Injury and filing of claim or notice... }\end{array}$ & $\begin{array}{l}\text { Los Angeles } \\
\quad 45 \text { days }\end{array}$ & $\begin{array}{l}\text { Chicago } \\
85 \text { days }\end{array}$ & $\stackrel{B o s t o n}{-}$ & $\begin{array}{l}\text { Medford } \\
\text { I8 days }\end{array}$ & \\
\hline Filing of claim and rejection or & & & & & \\
\hline $\begin{array}{l}\text { Rejection of claim and filing of suit. } \\
\text { Rement }\end{array}$ & $\begin{array}{l}03 \text { days } \\
\text { x20-50 days }\end{array}$ & 一 & I20 days & $\begin{array}{l}\text { I8r days } \\
\text { 210 days }\end{array}$ & $\overline{\text { Austin }}$ \\
\hline 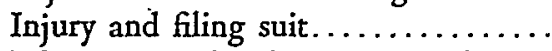 & 225 days & 175 days & - & $\mathrm{I}_{4} \mathrm{mo}$. & 34 days \\
\hline Filing suit and judgment or settlement & 5-ro mo. & 6-2I mo. & - & $8 \mathrm{mo}$. & \\
\hline Judgment dismissal $\ldots \ldots \ldots \ldots \ldots$ & - & $12 \mathrm{mo}$. & - & - & 34 days \\
\hline Settlement after suit $\ldots \ldots \ldots \ldots$ & 一 & I3 mo. & - & - & - \\
\hline Judgment on merits $\ldots$. & - & I8 mo. & - & - & - \\
\hline Judgment and payment. ................ & 30 days* & 4 yrs. & 2 yrs. & & $4-5 \mathrm{mo}$. \\
\hline
\end{tabular}

Disadvantages to Cities. The determination of public liability cases by juries frequently is decried. In part, the city suffers from the jury's $e x$ post facto and inexpert determination of what constitutes "reasonable care" to be exerted in the conduct of highly complex and complicated technical functions. This is nowise a feature peculiar to municipal corporation cases. But where the duty of care itself must be defined by a jury, involving not only technical questions but also functions and procedures established by statutes and ordinances, which often have no counterpart in private activities, there is a great lack of certainty. This is illustrated by two cases in Los Angeles where in one suit the city was held liable for the damage caused by water escaping from an aqueduct and in a companion suit involving the same circumstances was held not liable. Frequently, the city official who avoids the implications of one verdict against the city in performing his duties, may thereby become liable in a second, the conduct which got him into trouble in the first instance being held the norm.

The individual who is held liable in one case for negligent drainage of water from his land may never again be in the courts in such a matter. But the multiple relationships of the city to its residents does not allow of piecemeal determination of the duties it owes to them individually in providing drainage. Standards must be set up; but the standards set up in jury trials determine nothing except the instant dispute. They cannot safely be followed as fixing the duty of care of officers and employees. 
Disadvantages to the Claimant. The lack of experience of members of the bar generally in matters concerning municipal corporation law is one of the greatest handicaps of the claimant. In large communities, there are specialists in this type of practice, yet there is correspondingly less likelihood that the average practitioner will have any specialized knowledge concerning this body of law. In matters involving injuries to persons and property, it frequently is assumed that the law applicable to individuals or private corporations applies. Then developments in court prove that it does not, to the prejudice of the claimant. The cry for reform in the field of municipal liability law comes in part from lawyers who have been betrayed by their ignorance in this field. However, the growing expansion of governmental regulation is quickly acquainting the bar with the need to study the statutes in all matters affecting government. With this trend, fewer litigants will be impaled upon the deficiencies of their advocates. Where competent lawyers are employed, the requirements of liability statutes may advance, rather than retard, the claimants' chances of recovery.

Expense of Judicial Determination. This is a major deterrent of tort actions, especially those in which small recoveries may be involved. In these the proportion of possible recovery to be paid out in lawyer's fees may be the same as in a suit for many times the amount; but the time lost by the claimant, the out-of-pocket expenses, and the advances for costs (possibly to be lost) often deter prosecution of the case. It is in the large suits, and not the small ones, that a jury has the best chance to "add in" to a verdict an unofficial allowance for the lawyer's fee.

Advantages to Cities. Any tort recovery is predicated upon a breach of duty by an officer or employee of a city. There are many activities for which statutes or ordinances attempt to lay down the modus operandi. Some of these activities are hazardous. Where the legal duty of care in their performance is not readily discernible from the tests applicable to private relationships, the only authoritative interpretation can be obtained by judicial decision. Hence, many causes which seem simple to the claimant are appealed by cities defendant to higher courts as "test cases." This is a necessity to the city, but the claimant dislikes being made the "guinea pig" and being forced to the appeal, when any number of other causes might have been selected for the test.

Advantages to Claimant. Personal injury actions tried before juries may result in greater recompense for elements of pain and suffering than are obtained in settlements. Wherever there are fixed elements of damage, such as property items, this advantage decreases. The popularity, or lack of popular approval, of a political administration may have some small effect on verdicts against the city. In general, the same advantages accrue to the litigant that accrue in tort liability litigation against public utility companies. In small communities where jurymen are more likely to be property owners than in the large, the speculative advantages are cut down. This is evened up in some jurisdictions where change of venue may carry the action to a neutral geographical forum. 